\title{
Defensive behavior of the green snake Philodryas viridissimus (Linnaeus) (Colubridae, Reptilia) from the Atlantic Forest in Northeastern Brazil
}

\author{
Otavio A.V. Marques ${ }^{1}$
}

The green snake Philodryas viridissimus (Linnaeus, 1758) (Colubridae) is diurnal, arboreal and inhabits rain forests in South America (DIXON \& SoINI 1977). Here I report on the defensive displays of an individual from the Atlantic forest near Porto Seguro (16 $26^{\prime}$ 'S, $\left.39^{\circ} 05^{\prime} \mathrm{W}\right)$, Bahia, northeastern Brazil. The specimen (male, snout-vent length $=790 \mathrm{~mm}$, tail $=290 \mathrm{~mm}$ ) was preserved as voucher in the Instituto Butantan collection (IB 57195).

After its capture the snake was kept on a branch in the field and I elicited its defensive behavior by approaching and touching it. The defensive display includes lateral compression of the body, S-coil posture, open mouth, and striking (Fig. 1).

Lateral compression display is found among several arboreal snakes (GREENE 1979) but is unusual, if present, in other species of Philodryas (SAZIMA \& HADDAD 1992). The genus Philodryas includes both arboreal and terrestrial species (VITT 1980; SAZIMA \& HADDAD 1992). The green coloration, extreme angulation of the ventral scales and the lack of sexual dimorphism in tail length of $P$. viridissimus (FOWLER \& SALOMÃO 1994) suggest that this snake is one of the most arboreal species within the genus Philodryas. Thus, it is plausible that the defensive display with lateral compression of $P$. viridissimus is a derived trait associated to arboreality (cf. GREENE 1979).

ACKNOWLEDGEMENTS. I thank M. Martins and I. Sazima who reviewed the manuscript.

\section{REFERENCES}

Fowler, I. \& M.G. SALOMÃo. 1994. A study of sexual dimorphism in six species from the colubrid snake genus Philodryas. The Snake 26: 117-122.

GrEENE, H.W. 1979. Behavioral convergence in the defensive display of snakes. Experientia 35: 747-748.

Dixon, J.R. \& P. SoINI. 1977. The reptiles of the upper Amazon basin, Iquitos region, Peru. Milw. Public. Mus. Contrib. Biol. Geol. 12: 1-91.

SAzIMA, I. \& C.F.B. HAdDAD. 1992. Répteis da Serra do Japi, sudeste do Brazil: notas sobre história natural, p.212-236. In: L.P.C. MorELLATO (Ed.). História natural da Serra do Japi. Ecologia e preservação de uma área florestal no sudeste do Brasil. Campinas, Editora Unicamp, Fapesp, $321 \mathrm{p}$.

1) Laboratório de Herpetologia, Instituto Butantan. 05503-900 São Paulo, São Paulo, Brasil. 


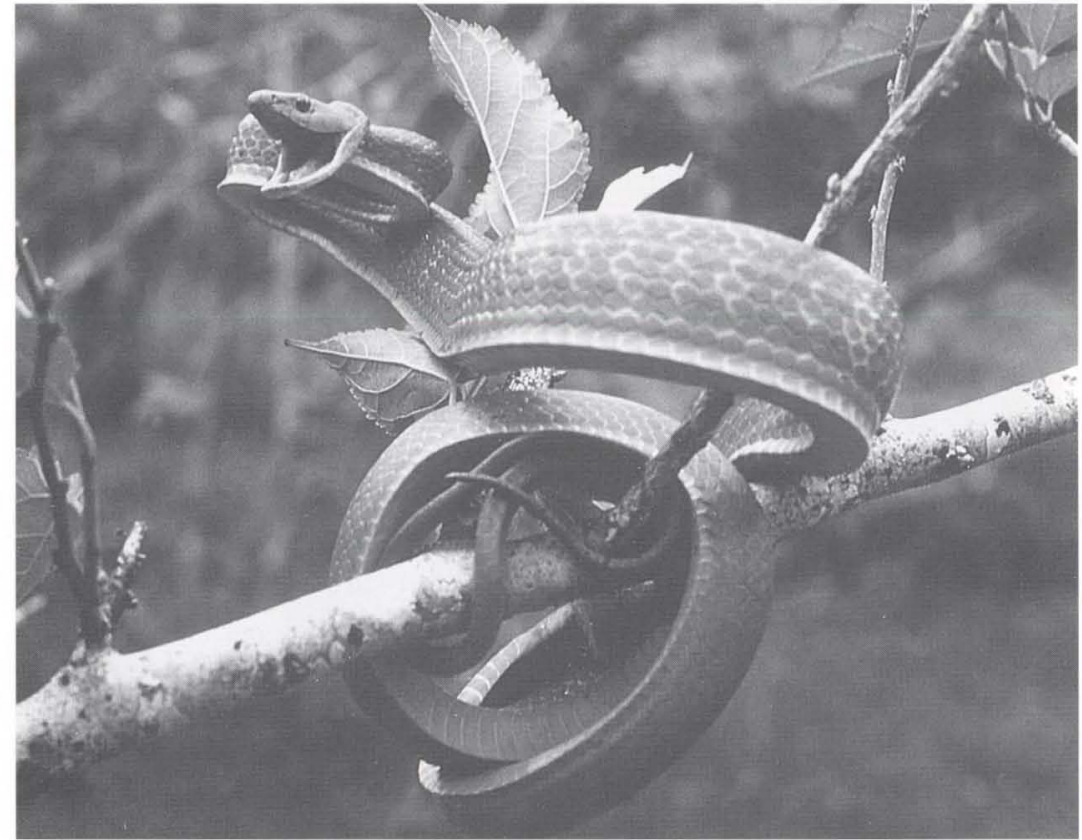

Fig. 1. Defensive display of Philodryas viridissimus. Note the protruding angulation of the ventrals scales due to lateral compression of the body.

VITT, L.J. 1980. Ecological observations on sympatric Philodryas (Colubridae) in northeastern Brazil. Pap. Avuls Zool. 34: 87-98.

Recebido em 31.X.1997; aceito em 01.III.1999. 